\title{
Ningxia halal industry financing problem research
}

\author{
Cheng xiaoqin \\ Business School of North Ethnic University \\ chengxq522@sohu.com
}

Keywords: halal products enterprises, financing, countermeasure

\begin{abstract}
The article takes halal products enterprises in Ningxia as the research object, analyzes halal products production enterprise's financing way and financing problem, and puts forward countermeasures and suggestions to solve financing difficulties in view of problems that exist in the process of Ningxia halal products enterprise financing
\end{abstract}

\section{Introduction}

Halal products enterprise refers to a new industry cluster which is given priority to halal food and Muslim supplies production. The direct objects of halal products are Muslim population, and the indirect object is general human consumption group. Halal products enterprises, therefore, have three characteristics: one is particularity---- product direct consumer groups are Islam spending habits people; second is universal----its indirect consumer groups can cover all human without cultural practices bindings; three is normative----halal products production, processing, storage and transportation, packaging, and management shall be conducted in accordance with the requirements of Islam.

Data of China Islamic association show that halal products enterprises are one of the fastest growing industries, including manufacturing, finance, logistics, retail, food and other industries, tens of billions of large international market. It is understood that halal products enterprises development in China in recent years has remained the growth rate of around $10 \%$.

Although halal products enterprises maintain a relatively high growth rate, compared with global market capacity, Ningxia's halal food trade accounted low in the total world trade. Especially in export, the proportion of the total amount is very low in world trade. Most halal products enterprises in Ningxia have small production scale and products' deep processing, fine degree are not high with low added value. In addition, they are scattered, and cannot form a centralized advantage, lacking of international brands. Although there are many reasons causing the above problems, unreasonable small capital stock, financing level, source, and structure, narrow financing channel and single financing way are the main factors affecting the overall development of Ningxia halal products enterprise.

\section{The Role of Ningxia Halal Products Enterprises in Ningxia Economy}

A. The number of Ningxia halal products enterprises is rising year by year

In recent years, the number of Ningxia halal products enterprises is growing. The halal products enterprises above designated size in 2009 totalled 154, which has risen to 204 by 2012. At present, Ningxia has formed more than 300 patents with a total of nearly 10 thousand production operators supplying halal food, Muslim supplies. In 2012, the whole autonomous region's industrial output value was about 9 billion yuan, and halal food industry output value accounted for $80 \%$ of the whole autonomous region food industrial outputs, which is shown in Table 1. The productions of Yinchuan Muslim industry industrial park, Wu Zhongqing Muslim halal food, and Muslim industry industrial park scale up and are standardized, which have formed a certain industrial cluster and scale effect. This has played an important role in Ningxia's economic development and social stability. 
Table 1 Ningxia halal products enterprises above designated size development

\begin{tabular}{|l|l|c|l|l|l|l|}
\hline Year & companies & employees & $\begin{array}{l}\text { total } \\
\text { revenue(ten } \\
\text { thousand } \\
\text { Yuan) }\end{array}$ & $\begin{array}{l}\text { profit (ten } \\
\text { thousand Yuan) }\end{array}$ & $\begin{array}{l}\text { added } \\
\text { value(ten } \\
\text { thousand } \\
\text { Yuan) }\end{array}$ & $\begin{array}{l}\text { tax (ten } \\
\text { thousand } \\
\text { Yuan) }\end{array}$ \\
\hline 2008 & 143 & 18836 & 1116250 & 72448 & 404102 & 5573 \\
\hline 2009 & 154 & 21306 & 1378656 & 108846 & 496841 & 10674 \\
\hline 2010 & 168 & 28050 & 1516250 & 134804 & 533384 & 14932 \\
\hline 2011 & 187 & 28322 & 1778656 & 182409 & 704152 & 18521 \\
\hline 2012 & 204 & 31312 & 20547689 & 221483 & 995641 & 23331 \\
\hline
\end{tabular}

Note: The data is from Ningxia Labor Statistical Yearbook Data Assembly (2008-2012).

B. Ningxia halal products enterprise is an important channel to absorb employment

The development of Ningxia halal products enterprises made an important contribution in absorbing employment and maintaining social stability. In recent years, Halal products enterprises in Ningxia rely on its flexible mode of operation, constantly expand the scale of production, provide a lot of jobs, and effectively ease social contradictions of laid-off and difficult employments. In 2008, Halal products enterprises above designated size in Ningxia absorbed nearly 18000 people. By 2012, personnel grew to 31000 people. They become the main channel of new employment. Rural investment with significant proportion of Halal products enterprise investment scale enlarged, which effectively solve Ningxia rural surplus labor force employment, increase farmers' income, and provide an effective way to solve the problem of "agriculture, rural areas and farmers".

\section{Financing Characteristics of Halal Industry in Ningxia}

Along with the deepening of economic development in Ningxia, halal products processing and the increasing number of production enterprises, the development of halal products enterprises plays an important role in Ningxia Hui autonomous region economic growth. Halal products enterprises met a lot of resistance in the process of development, however, with financing activity as a key problem. Financing problems, both relate to enterprise resource use efficiency and the sustainable development of the enterprise. Due to special economic development reform environment and Islamic ethnic characteristics of Ningxia halal products enterprises determine their different financing characteristics from other types of enterprises.

A. Ningxia halal products enterprise financing scale is growing

Table 2 Enterprises above designated size in Ningxia halal products financing scale (ten thousand

\begin{tabular}{|l|l|l|}
\hline Year & Financing scale & Financing growth (\%) \\
\hline 2008 & 291955 & \\
\hline 2009 & 572840 & 96 \\
\hline 2010 & 742237 & 36.93 \\
\hline 2011 & 964289 & 20.52 \\
\hline 2012 & 1256435 & 96 \\
\hline
\end{tabular}

Note: The data is from Ningxia Labor Statistical Yearbook Data Assembly (2008-2012)

As can be seen from Table 2, in 5 years, Ningxia halal products enterprises' financing scale is growing, and the growth rate is increasing. In 2012, the financing scale of halal products enterprises above designated size was nearly doubled.

B. Financing characteristics of halal products enterprise above designated size

1, Enterprises above designated size gives priority to exogenous financing

Enterprise financing way choice affects financing structure and financing structure is closely related to the enterprise value. Pluck the financing theory enterprise's financing can be divided into internal financing and external financing. Internal financing includes retained earnings and 
depreciation financing. External financing includes equity financing and debt financing. In developed countries, endogenous financing in enterprise's financing structure accounts for the highest; External financing, such as bank loans, corporate bonds, and other creditor's rights financing accounts are more than major, and the lowest proportion is equity financing.

From statistics:

Table 3 the financing structure of Ningxia halal products enterprise above designated size (ten thousand Yuan)

\begin{tabular}{|l|l|l|l|l|}
\hline Year & $\begin{array}{l}\text { Total } \\
\text { financing }\end{array}$ & $\begin{array}{l}\text { Endogenous financing } \\
(\%)\end{array}$ & $\begin{array}{l}\text { Exogenous financing } \\
\text { (equity capital \%) }\end{array}$ & $\begin{array}{l}\text { Exogenous } \\
\text { financing (debt \%) }\end{array}$ \\
\hline 2009 & 572840 & 7.53 & 30.9 & 61.57 \\
\hline 2010 & 742237 & 25.59 & 2.05 & 72.36 \\
\hline 2011 & 964289 & 22.54 & 24.88 & 52.58 \\
\hline 2012 & 1256435 & 27.95 & 13.33 & 59.72 \\
\hline
\end{tabular}

Note: The data is from Ningxia Labor Statistical Yearbook Data Assembly (2008-2012).

Table 3 shows, from the form, that Ningxia halal products company has a strong external debt financing preference. In 2009-2012, Ningxia halal products enterprise's endogenous financing is only $27.95 \%$ in maximum, and $72 \%$ capital is exogenous financing.

2 , the mode of foreign debt financing is mainly short-term bank borrowing way.

Table 4 the change trend of Ningxia halal products enterprise financing structure (ten thousand

\begin{tabular}{l|l|l|l|l|l|}
\hline Year & $\begin{array}{l}\text { Total } \\
\text { financing }\end{array}$ & $\begin{array}{l}\text { Endogenous } \\
\text { financing }\end{array}$ & $\begin{array}{l}\text { Exogenous financing } \\
\text { (equity capital \%) }\end{array}$ & $\begin{array}{l}\text { Exogenous } \\
\text { financing } \\
\text { (debt \%) }\end{array}$ & $\begin{array}{l}\text { Current } \\
\text { liabilities (\%) }\end{array}$ \\
\hline 2009 & 572840 & 7.53 & 30.9 & 61.57 & 87.8 \\
\hline 2010 & 742237 & 25.59 & 2.05 & 72.36 & 88.09 \\
\hline 2011 & 964289 & 22.54 & 24.88 & 52.58 & 90.13 \\
\hline 2012 & 1256435 & 26.95 & 13.33 & 59.72 & 85.13 \\
\hline
\end{tabular}

Note: The data is from Ningxia Labor Statistical Yearbook Data Assembly (2008-2012).

It can be seen from Table 4 that Ningxia halal products enterprises' debt ratio is higher. In 2008-2012, the asset-liability ratio of Ningxia halal products enterprise is between $43 \% \sim 59 \%$. In addition, from the debt maturity structure in recent years, Ningxia halal products enterprises' long-term debt ratio is very low with high current liabilities. Long term asset liability ratio is less than $12 \%$ on average, accompanied by the expansion of enterprise scale. The proportion of current liabilities increases year by year, and most are short-term bank borrowing.

C. Small businesses mainly rely on internal finance

In Ningxia halal products enterprises, enterprises with fewer annual sales and staff take larger proportion in internal financing. But as the scale of enterprise organization grows, the proportion of exogenous finances gradually increases. In small businesses, such as halal products company worker fewer than 50 people and annual sales less than 5 million Yuan, nearly $86 \%$ of the enterprises give priority to endogenous financing.

\section{Existing Problems}

A. Strong enterprise financing demand and acute shortages in funds 


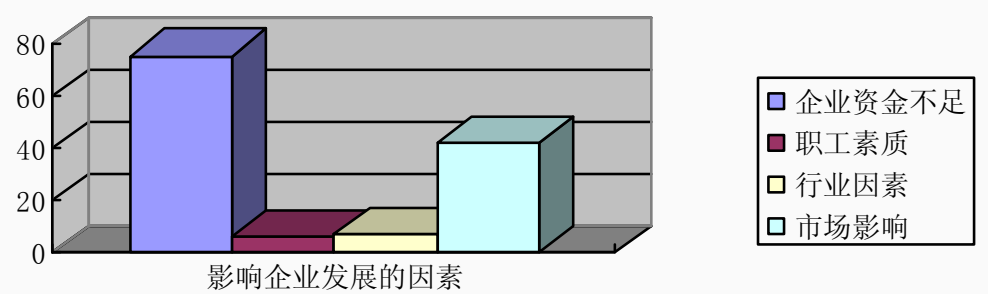

Figure 1 Halal products enterprise development factors

It can be seen from Figure 1 that fund shortage is the most important factor restricting the development of Ningxia halal products enterprises. In the survey, $75 \%$ of halal products business owners think that in expanded reproduction and simple reproduction, insufficient funds are the primary obstacle of the development of halal products enterprise, and therefore enterprises lose a lot of development opportunities.

B. Halal products enterprise's high dependence of financial institutions, and low rate of financial institutions loans

The asset-liability ratio of halal products enterprises above designated size in Ningxia is generally higher than $70 \%$, and the main source of debt is financial institutions loan. Enterprise rely on financial institutions loans by more than $80 \%$, and the proportion is $40 \%$ below the east of Wenzhou. The loan amount cannot satisfy the needs of the development of enterprises.

C. Single enterprise financing and high risks

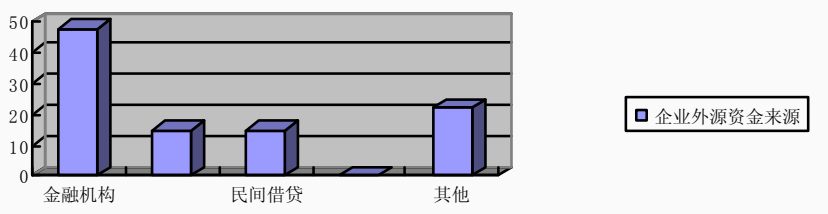

Figure 2 Exogenous financing sources

Figure 2 shows that in Ningxia halal products enterprises, in addition to $48 \%$ of corporate loans is from financial institutions, 15\% exogenous financing mainly comes from commercial credit, 15\% comes from commercial paper, $9 \%$ comes from private individuals or institutions, $12 \%$ other sources, and bond and open market operations account for only 4\%. This means: Ningxia halal products enterprises financing channels are not improved well for many years. In recent years, it has not been very well developed by folk financial and stock market listing or issuing bonds to finance.

D. The difficulty of enterprise credit loans increases, and private lending public phenomenon is common

Most small businesses engaging in halal products production is very difficult to obtain credit in name of a legal person. Some enterprises business owners can only access to credit in name of a natural person, namely: private lending. The main reason is that on the one hand, banks worry about the long-term stability of the enterprise; on the other hand, banks are suspicious about the authenticity of enterprise financial statements. Loans with entrepreneurs' family property as collateral can reduce the risk of financial institutions. But small business owners' personal family housing mortgage loans are very limited, so the financing is very limited, which is unable to support the needs of the enterprise long-term stable development.

\section{The Causes of Problems in Ningxia Halal Products Enterprise Financing}

A. External cause

1 , relatively backward social credit management system in our country

So far, there is no perfecting enterprise credit evaluation; credit investigation and credit guarantee system in our country. Especially the absence of credit of commercial Banks and other financial 
institutions in small and medium-sized private enterprises increases the cost and risk of offering loans to small and medium-sized enterprises. This to some extent restricts the financing ability of halal products enterprises.

2, Backward financial reform and development

On the one hand, financial institutions ask higher for halal products enterprise finance financing cost; On the other hand, enterprises pay more money to financial institutions. Despite the big four state-owned commercial Banks' small and medium enterprises loan department established for financial services to small and medium-sized enterprises in accordance with relevant stipulations according to "About Further Improvement for a Service for Small and Medium-sized Enterprises". But in practice, because of higher financial risk of small and medium-sized enterprise itself, it leads to some commercial banks would rather increase investment in Treasury bonds than loan to small and medium-sized enterprises business. This makes the financing difficulties for the development of Ningxia halal products enterprises.

3, less favorable policies or weakened enforcement effect for halal products enterprise investment and financing

For accelerating the economic development of ethnic minority areas, in the "eleventh" first five-year plan outline of national economy and social development, the development of the western region is clearly put forward to promote. Support resources advantage transition into industrial advantage, and develop characteristic industry, and implement "three cares", such as tax incentives, financial support policy in national trade and national supplies manufacturing enterprises. But in the survey, most of the investors in the country's halal products enterprises are still very much looking forward to preferential policies. Enterprises enjoy narrow preferential policies. It even tends to appear far-left, makes investors feel policy instability and discontinuity with big investment risk. Some preferential policy is not in place.

4, Financing policy environment and financial market environment halal products enterprises facing determine the progressiveness of financing policy.

In financing process, Ningxia halal products enterprises operate assets by current liabilities financing, which not only satisfy short-term funding needs, but satisfy the need for the funds to finance long-term assets. This is a high risk, high expected income financing policy. Many enterprises have seen high risk and high income of this radical financing policy. Ningxia halal products enterprises choose the financing policy because of macro policy restriction and relatively single underdeveloped financial market structure, etc. Under the constraints, it is a kind of helpless choice. The main reason is that Ningxia halal products enterprises cannot meet the long-term capital demand of enterprise sustainable development through internal financing, and need to expand external financing. And halal products enterprises are relatively backward due to the limitation of external financial environment, normally only with short-term debt financing. Long-term debt capitals shut out smaller halal products enterprises because of ownership discrimination by financial institutions and external equity capital markets, so that short-term liabilities should not only meet the need for short-term assets funds, but also meet the needs of enterprises’ long-term capital.

B. Internal reasons

1, exogenous financing: the inevitable choice of private enterprises in high-speed growth

Halal products enterprises in Ningxia are overall small sized, financial risks are higher, and enterprise self-accumulation alone cannot satisfy the company expands' money demand. Therefore, in order to achieve the survival, expansion and development of the enterprise can be implemented by expanding external debt and equity capital financing way.

2, Low profitability is the important factor of Ningxia halal products enterprises expanding external financing

Through the capital profit margin of halal products enterprises from 2008 to 2011 in Ningxia, according to the results, Ningxia halal product enterprise operating performance and profitability are overall weaker (details see Table 16). In recent years, Ningxia halal products enterprise scale's expansion speed is faster and faster, and the external dependency of short-term debt funds is in the growing, and the dependency on the decline of equity funds is declining, and the internal 
self-accumulation of dependency is declining. This to some extent reflects Ningxia halal products enterprise asset quality is deteriorating. Therefore, with the passage of time, some low asset-liability ratios also join in the high debt, but this is not rational choice of the enterprise based on capital structure. This is a necessity choice relying on internal accumulate due to enterprise profit inability.

Table 5 Ningxia halal products enterprise capital structure and capital profit margin trends units: \%

\begin{tabular}{|l|l|l|l|l|}
\hline & 2008 & 2009 & 2010 & 2011 \\
\hline $\begin{array}{l}\text { Asset-liability } \\
\text { ratio }\end{array}$ & 75.08 & 68.05 & 68.08 & 66.98 \\
\hline $\begin{array}{l}\text { capital profit } \\
\text { margin }\end{array}$ & 4.36 & 5.6 & 5.7 & 5.9 \\
\hline
\end{tabular}

Note: The data is from Ningxia Labor Statistical Yearbook Data Assembly (2008-2012).

3 , the uncertainty of halal products enterprises

Halal products enterprises' asset quality is not high and the management risk is increasing. These are important causes leading to enterprise financing difficulties. Although Ningxia halal products enterprises in general have the characteristics as advantages of small size, flexible operation, and fast transformation of business model, but flexible mode of operation often expects investment income instability, management risk, and financial risk. Compared with large enterprises, its ability to avoid risk is poorer, and the probability of bankruptcy is higher. In investment to halal products enterprises, financial institutions, and other outside investors commonly adopt way to improve the credit risk control coefficient, which generally lead to less investment amount.

4, Halal products enterprises lack financing planning consciousness

In the implementation of specific financing options, Ningxia halal products enterprises adopt two ways: one is planning by taking financing activities as independent financial activities. When the enterprise's operating cash flow does not match investment need, enterprises lack funds or idle, which affect the efficiency of the use of funds; two is not enough attention to the importance of enterprise capital structure, often bearing high debt, too big financial risks, and lose the benefits of indebtedness.

5, Halal products enterprises' not enough emphasis on the enterprise good faith construction

From the overall situation, halal products enterprises mostly ignore enterprise's credit construction. Quite a number of halal products enterprises have low credit, less guarantees and collateral, thereby increasing the loan risk of financial institutions to halal products enterprises. From halal products enterprises' internal situation analysis, halal products enterprise generally gives priority to small and medium-sized enterprises. Under the condition of fierce market competition, enterprises are facing problems like backward internal management system, not standard financial and internal control system, low credit consciousness, enterprise good faith construction ignorance, which cause difficulties for the enterprises in mortgage loans. Some halal products enterprises escape the bank debt in reformation and lead to the deterioration of the relationship between them and banks.

\section{Countermeasures for Ningxia Halal Products Enterprises to Get Out of Financing Predicament}

A. Strengthen government financing policy support

1, Increase financial support for halal products enterprises in Ningxia

Improve and perfect the financial service system for halal products enterprises services fundamentally strengthens a powerful guarantee for the financial support of halal products enterprises. A theoretical explanation for Ningxia halal products enterprises is the information asymmetry between them and banks, that is, halal products enterprises are mostly small and medium enterprises, the authenticity of the provided financial statements, collateral, and the credit are not accepted by banks and other financial institutions. Enterprise information credibility is low, and the financial 
institutions of information acquisition cost are very high. Generally big banks serve large enterprises, and small and medium-sized banks serve small enterprises. The number of small and medium-sized banks in China is very different from the development of small and medium-sized enterprises demands. The unreasonable financial services structure is also one of the causes of financing difficulties of small and medium-sized enterprises. In order to change this situation, the existing financial institutions should constantly improve their management and service ability for small and medium enterprises, strengthen the consciousness of service for small and medium-sized enterprises and increase financial support for potential profitability of small and medium-sized enterprises, and improve the service efficiency of bank funds.

2, Improve Ningxia halal products enterprises’ external financing environment

First of all, innovate the concept of halal products enterprises. To improve Ningxia halal products enterprises' external financing environment, concept of innovation of halal products enterprises should be started with. Deepening economic reform, first of all, must have the innovation on ideology, give private property rights and state-owned property rights in the equal position in the market economy, make all kinds of system of ownership of enterprises in the market, are equal to participate in the competition, and compete to promote the development and perfection. The state-owned commercial banks' mainly in the service of guiding ideology of state-owned large and medium-sized enterprises must be changed, in the choice of industry and benefit as a loan object, rather than discrimination of ownership; To increase funding for halal products high and new technology enterprise, and the development of key support high content science and technology and market potential of halal products enterprise; Encourage technical innovation and upgrading of halal products enterprises to offer the guarantee for capital in healthy development of halal products enterprises.

Second, promote halal products enterprise credit system construction, and improve enterprise halal products financing ability. Enterprise credit is the cornerstone of market economy, and is also the premise of solving halal products enterprise financing problems. On the one hand, gradually establish and perfect our country small and medium-sized enterprise credit evaluation system; On the other hand, actively carry out enterprise internal monitoring and construction of credit system, strengthen the enterprise internal financing ability, and improve the financing ability of the enterprise.

Moreover, foster diversified equity financing way. Development of risk investment, such as investment funds promotes the development of halal products economy in Ningxia. In recent years, risk investments abroad vastly promote a large number of enterprises from the transformation of scientific and technological innovation to the real economy, and promote the development of local high-tech enterprises. In our country, Venture Capital Investment Company can invest small and medium-sized enterprises by combination form of equity and debt with convertible preferred stock and convertible bonds. Investment can not only obtain short-term profit, but is targeting mature investment in the invested enterprise equity appreciation for equity transfer after long-term high returns, in order to extend halal products enterprise equity financing channels.

Finally, according to the actual situation of Ningxia halal products enterprises, enterprises financing and bond financing in the primary market meet with difficulties. So, our government should strive to develop relevant incentives to guide enterprises to small and medium-sized enterprises board. Tax is one of the most direct encouragement measures, which is helpful for halal products small and medium-sized enterprises' self-capital accumulation. On the one hand, the enterprise financial market melt money in small and medium-sized plates, and get tax preferential again at the same time. This can cause the sustainable development of the enterprise and on the way of benign development. On the other hand, through a series of preferential policies, make enterprise evolution, and optimize Ningxia halal enterprises products development on the whole

B. Improve the ability of enterprise financial management

At present, Ningxia halal products enterprises should speed up the reform of the enterprise itself from the following several respects:

1, Improve the overall management quality and management level of enterprises 
Ningxia halal products enterprises should get out of the pitfalls of family-based management model by family holding, but in order to realize property rights to make the development of enterprise more dynamic. Enterprise operators and managers should strengthen their own learning, timely understand and master the modern enterprise management concepts and methods, be familiar with industry development trends, and constantly explore new train of thought, establish the innovative consciousness, develop and adapt to the enterprise management system and measures, and make the management more scientific, persistent and informationized.

2 improve enterprise financial and internal control system. It is the main way of improving the quality of corporate financial information and transparency and strengthening the construction of enterprise credit.

Endogenous financing is not only the basic guarantee of enterprise investor rights and interests, but the basic way to optimize enterprise resource configuration and improve the financing efficiency of enterprises. Therefore, Ningxia halal products enterprises' financial management personnel must be familiar with enterprise's profit distribution policy theory. Combining the specific conditions in the enterprise, formulate the distribution system for enterprise's development, and fully deal with the relationship between enterprise accumulation and distribution of surplus.

3 , Perfect the corporate governance structure, and improve the use efficiency of enterprise funds.

The improvement of enterprise performance depends largely on the effectiveness of the internal governance structure. Internal corporate governance structure specification or not only relates with the effective implementation of the enterprise investment decisions and financing decisions, but also affects the efficiency of management of enterprise and internal staff's cohesive force.

\section{References}

[1] Ma Yajun, Song Lin. Enterprise financing efficiency and theoretical analysis framework [J]. Journal of Jilin Taxation College Journal, 2004, (2)

[2] Wang Juan, Yang Fenglin. The latest progress in the study of cash flow based on modern capital structure [J]. Journal of Foreign Economics and Management, 2002,01:5-6.

[3] Niu Jiangao Cao Min. Analysis of characteristics of private enterprise financing structure and capital structure: take Hebei province for example [J]. Journal of Shijiazhuang School of Economics, 2008, 11:46-60.

[4] Ningxia Area Statistics. Statistical yearbook 2007, Ningxia [M], Beijing: China Statistics Press.

[5] Ningxia Area Statistics. Statistical yearbook 2008, Ningxia [M], Beijing: China Statistics Press.

[6] Ningxia Area Statistics. Statistical yearbook 2009, Ningxia [M], Beijing: China Statistics Press.a 